\title{
Indonesian Language Learning Based on Teachers' Directive Speech Act Strategy (TDSAS) and Students' Positive Affective Color Response (SPACR) with a Synectic Model
}

\author{
Sumarti \\ FKIP Universitas Lampung, Indonesia \\ Iing Sunarti \\ FKIP Universitas Lampung, Indonesia \\ Mulyanto Widodo \\ FKIP Universitas Lampung, Indonesia
}

\begin{abstract}
Love and self-esteem can be fulfiled by the teacher through teachers' directive speech act strategy (TDSAS). Teachers need to use teachers' directive speech act strategy to make the students feel loved and respected and emerge the students' positive affective color response (SPACR) which creates a fun, effective and conducive learning process. Some verbal abuses made by the teachers affect the students' psychology (inferiority, trauma, laziness, and has no motivation to come to school). This study aimed to portray the Indonesian language learning in junior high school using TDSAS-SPACR with a synectics model to improve the quality of the process and learning outcomes. Using the descriptive-qualitative method, the results showed that the TDSAS based learning which emerges SPACR creates an effective and fun Indonesian language learning in junior high school.
\end{abstract}

Index Terms - teachers' directive speech act strategy, affective color response, synectics model

\section{INTRODUCTION}

The realization and the selection of teachers' directive speech act strategy (hereinafter referred to as TDSAS) play an important role in learning. They are closely related to the students' affective color response both positive and negative since they influence the learning effectiveness (Zhang, 2011). In his research, Fried (2011) shows that in learning, affective color or emotion greatly influences the cognitive learning process, motivation and class' interaction. Emotion increases the cognitive process and it becomes an integral part of the learning process.

TDSAS can be used to create the students' optimal competencies and trigger the students' self-actualization. Maslow in Slavin (2011) states that each student has deficiency needs; physiological needs, safety needs, love, and belonging needs as his/her basic needs before the growth needs emerge. The students' growth needs include knowing and understanding, aesthetics, and self-actualization.

The teachers should admit that the learning process will be disrupted when the students' basic needs are not fulfilled. The most important deficiency needs are love and self-esteem. The students who feel unloved and unappreciated even though they are capable, will not be able to have strong a motivation to achieve goals in growth needs (Stipek, 2001). The teachers who can soothe the students and make them feel accepted and appreciated as an individual will help the students enjoy learning and be creative in building their self-actualization.

The nature of education as stipulated in the National Education System in Law number 20 act 1 (2003) states that "education is a conscious and planned effort to create a learning process and atmosphere so that the students actively develop their potential to have religious strength, self-control, personality, intelligence, noble character, and achievable skills". Hence, the TDSAS and students' affective color response research in learning are important. In addition to the theoretical background and policy base mentioned earlier, this research is based on the empirical study in the field.

Numerous physical and non-physical abuses done by the teachers to the students still can be found in the educational environment as reported in newspaper and electronic media. Those physical abuses are related to the educational activities, in which by Charters, (in Susilowati, 2013) are interpreted as abuses (both physical and non-physical abuse) done by the teachers to the students for disciplinary reasons. Those abuses result in physical and physiological injuries. The physical abuse includes punishment, persecution, beatings, and rape, meanwhile verbal 
non-physical abuse includes cursing, snapping, and insulting. Psychological nonphysical abuses include looking at the students cynically and condescendingly, ostracizing, ignoring, and embarrassing the students.

In her research, Sumarti (2015) finds that teachers' directive speech act strategy created students' affective color response, both positive and negative. This finding confirms McDonald (2011) who states that when the teachers speak in the learning process, the students subconsciously respond affectively. Moreover, Jansen (2010) states that when the students have been humiliated or demeaned in front of the class by the teacher in their childhood, it leaves an emotional scar. For students, emotion is the most memorable thing in learning. Emotion influences belief, decision, and action. Its effects will last and the emotional strength immediately occurs. The positive emotion built is associated with the students' success at school (Jensen, 2010). Therefore, in directive speech, the strategy to trigger the positive emotion is needed to create a fun learning and make the students feel excited to do the tasks.

By having passion and enthusiasm, the students' competency can be explored and the learning objectives will be achieved. This effective teachers' speech strategy orientation will emerge the students' creativity and productivity. The teachers who can soothe the students and make them feel accepted and appreciated as an individual will help the students becoming creative for their self-actualization. Teachers' directive speech act strategy and students' affective color response can fulfill the students' deficiency needs which then will make the students feel motivated to fulfill their growth needs.

Love and self-esteem, as the students' basic needs, can be accommodated through TDSAS. TDSAS which emerges the students' positive affective color response (hereinafter referred to as SPACR) to create an effective, fun and conducive to learning and also improve students' confidence can be applied to preserve the students' feeling, to feel loved and appreciated (Ormrod, 2009).

By using Brown and Levinson's speech strategy parameters (1987), it is discovered that TDSAS which emerges SPACR are (a) direct speech, (b) praising, (c) using terms of endearment or name, (d) avoiding using the words saya (I) and kamu (you), (e) involving speakers and interlocutors in activities, (f) using polite request, (g) containing jokes and humor, (h) considering the interlocutor's wishes, (i) seeking agreement, and (j) indirect speech. Meanwhile, the teachers' directive speech act which results in students' negative affective color response (hereinafter referred to as SNACR) are (a) sarcastic indirect speech, (b) greeting in high tone, (c) comparing, and (d) insulting (Sumarti, 2015).

Education creates ideas and emotions continuously (Joyce et al. 2012). Changes in human awareness occur endlessly and it gives a distinctive character to the educational process. Therefore, learning becomes a joyful and lifelong process. Good teaching is a boundless learning experience on how ideas and emotions interact with the classroom atmosphere and how both can change according to the changing atmosphere (Joyce, 2012)

Every learner has great potential to develop. Educators are expected to be able to explore and develop the students' potential by providing the opportunities for students to be actively involved in expressing all of their potential, such as by using the application of synectics learning. This learning emphasizes the students' active involvement to experience themselves and solve problems so that their potential develops optimally.

Improving the quality of the process and the result of Indonesian language learning can be done in various efforts. This study tries to discover the TDSAS which brings out positive emotional responses from students to prompt their enthusiasm and learning creativity. The students' positive behavior can improve students' learning outcomes. The professional teachers can encourage and motivate the students to learn. The learning products should improve students' previous competencies. The learning process will depend on teachers' performance and personality, students' attitudes, and learning facilities assuming that conducive learning will affect teachers' performance and students' learning achievement.

Speech act strategy relates to ways of speaking or speaking technique. Each speech act has a realization strategy. Yule (1996) reveals that strategy is a tendency to use certain lingual forms as a consideration of the social distance between speakers and speech partners. As an example, the solidarity strategy is used by the speakers because of their closeness to the interlocutor who uses a nickname or term of endearment, or another expression due to intimacy.

To maintain the effectiveness of the learning process, as the educators, the teachers should know and understand the positive and negative impacts of emotions on learning (Fried, 2011). In his research, Zhang (2007) reveals that the TDSAS, especially teachers' request speech act, has an impact on the students' emotions and behavior. Therefore, the study of affective color or emotion associated with the teacher and student interaction context in learning is very essential. The emotions are very important for students' motivation, learning, performance, identity development, and health (Schutz \& Pekrun, 2007).

In 2005, Sumarti has done researched on teachers' directive speech act and students' affective color response. She brings out some findings as follows: (1) the communication function of teachers' directive speech in Indonesian language learning consists of ordering, requesting, prohibiting, suggesting, asking, and inviting; (2) based on structure compactibility (locutionary) and communication function (illocutionary), teachers' directive speech is realized directly and indirectly; (3) teachers' directive speech strategy is directly realized by imperative structure, while indirect teachers' directive speech strategy is realized using rhetorical question strategy, giving clues, tautology, ellipsis, insinuating, and comparing; (4) the politeness strategies used in teachers' directive speech are positive politeness strategy (paying attention to the interlocutor, giving compliment, paying attention to the interlocutor's needs, using terms of address, seeking for agreement, avoiding dissent, giving appreciation, involving the speakers and interlocutors 
into activities and using jokes) and negative politeness strategy (indirect speech, using questions, and avoiding the use of words saya (I) and kamu (you)); (5) teachers' directive speech act strategies (TDSAS) which emerges students' positive affective color response (SPACR) are; (a) direct strategy, (b) praising, (c) using term of endearment and name (d) avoiding the use of words saya (I) and kamu (you), (e) involving speakers and interlocutors in activities, (f) using polite request, (g) using jokes, (h) considering the interlocutor's wish, (i) seeking for agreement, dan (j) indirect speech; (6) teachers' directive speech act strategies (TDSAS) which emerges students' negative affective color response (SNACR) are; (a) indirect speech containing irony, (b) greeting using exclamation, (c) comparing, and (d) speech containing admonishment.

These findings emerge the issues of whether TDSAS which generated SPACR is applicable as the basis or reference in managing the learning process with a synectic model. Thus, this research aimed to (1) identify the purpose of Indonesian language learning based on TDSAS-SPACR with a synectic model; (2) describe the design of TDSAS-SPACR-based learning model; (3) demonstrate the effectiveness of Indonesian language learning based on TDSAS-SPACR with a synectic model in Junior High School.

\section{RESEARCH METHOD}

This research used a descriptive qualitative method. The research was conducted in SMPN 22 (Public Junior High School) and SMP IT Fitrah Insani (Private Junior High School) Bandar Lampung, Indonesia. The data were collected continuously for three months. In collecting the data, observation, audio-visual recording, questionnaire, interview, and test were used in this research. The observation technique and audio-visual recording were used to collect the learning process data which covered students' activities and TDSAS-SPACR-based learning with a synectic model. Questionnaire and interview were used to collect students' and teachers' responses toward the use of TDSAS-SPACR- based learning model, while the test was used to measure the students' writing skills before and after using TDSAS-SPACR- based learning with a synectic model.

\section{RESULT AND DISCUSSION}

In her previous research, Sumarti (2015) found that the communicative functions of teachers' directive speech act in Indonesian language learning in junior high school involve ordering, asking, forbidding, suggesting, asking, and inviting. The use of communicative functions can be seen on the table (1) below.

TABLE 1

COMMUNICATIVE FUNCTION OF TEACHERS' DIRECTIVE SPEECH IN INDONESIAN LANGUAGE LEARNING IN JUNIOR HIGH SCHOOL
\begin{tabular}{|c|c|c|c|c|c|c|c|}
\hline \multirow{2}{*}{ Domain } & Ordering & Asking & $\begin{array}{c}\text { Forbiddin } \\
\mathrm{g}\end{array}$ & $\begin{array}{c}\text { Suggestin } \\
\mathrm{g}\end{array}$ & Asking & Inviting & Total \\
\cline { 2 - 8 } & 41 & 14 & 8 & 5 & 3 & 5 & 76 \\
\hline $\begin{array}{c}\text { Indonesian language } \\
\text { learning in seventh grade }\end{array}$ & 82 & 40 & 2 & 7 & 18 & 8 & 157 \\
\hline $\begin{array}{c}\text { Indonesian language } \\
\text { learning in eighth grade }\end{array}$ & 35 & 13 & 21 & 16 & 14 & 5 & 104 \\
\hline $\begin{array}{c}\text { Indonesian language } \\
\text { learning in ninth grade }\end{array}$ & 158 & 67 & 31 & 28 & 35 & 18 & 337 \\
\hline Total & & & & & & & \\
\hline
\end{tabular}

Based on table (1), the communicative function of teachers' directive speech is dominated by ordering, while inviting is the least communicative function done by the teachers. This finding supports Zhang (2011) who argues that teachers often produce a directive speech of ordering or dictating and sometimes they tend to enforce the students. Therefore, the teachers should speak politely which will not threaten the students' self-esteem. The table below shows examples of communicative functions of teachers' directive speech analysis in Indonesian language learning in junior high school. 
TABEL 2

THE ANALYSIS OF COMMUNICATIVE FUnCTION OF TEACHERS' DiRECTIVE SPEECH IN INDONESIAN LANGUAGE LEARNING

\begin{tabular}{|c|c|c|c|c|}
\hline No. & Domain & Context & Participant & Directive speech \\
\hline 1. & $\begin{array}{l}\text { Indonesian Language } \\
\text { Learning in seventh } \\
\text { grade }\end{array}$ & $\begin{array}{l}\text { The students were busy with } \\
\text { speed reading ability test and } \\
\text { they were noisy. The teacher } \\
\text { asked them to keep quiet by } \\
\text { using an imperative sentence. }\end{array}$ & Student: & $\begin{array}{l}\text { "Dengarkan dulu penjelasan Ibu!" } \\
\text { ([Me-1/Tl] } \\
\text { (Listen to me first!" [Me-1/Tl] } \\
\text { (immediately fell silent and paid } \\
\text { attention to the teacher's explanation) }\end{array}$ \\
\hline 2. & $\begin{array}{l}\text { Indonesian language } \\
\text { learning in seventh } \\
\text { grade }\end{array}$ & $\begin{array}{l}\text { Learning had just begun, and } \\
\text { the students were noisy while } \\
\text { the teachers had just started } \\
\text { explaining the short story. The } \\
\text { teacher used an interrogative } \\
\text { sentence with a low tone to ask } \\
\text { the students to be quiet and } \\
\text { calm. }\end{array}$ & Teacher: & $\begin{array}{l}\text { "Sudah bisa dengarkan Ibu?' } \\
\text { [Me-77/TTI/Int] } \\
\text { "Are you ready for listening to me?" } \\
\text { (all the students were silent while } \\
\text { smiling then looked at the teacher } \\
\text { seriously). }\end{array}$ \\
\hline 3. & $\begin{array}{l}\text { Indonesian language } \\
\text { learning in eighth } \\
\text { grade }\end{array}$ & $\begin{array}{l}\text { The teacher scolded the student } \\
\text { who opened the Math book and } \\
\text { asked the student to put the } \\
\text { book in the bag and open the } \\
\text { Indonesian language subject. } \\
\text { The teacher used a declarative } \\
\text { sentence. }\end{array}$ & Teacher: & $\begin{array}{l}\text { "Eeh...sekarang pelajar-an Bahasa } \\
\text { Indonesia bukan Matematika." } \\
\text { "Hey... It's an Indonesian Language } \\
\text { subject now, not Math!" } \\
{[\mathrm{Me}-73 / \mathrm{TT} / \mathrm{Dek}]} \\
\text { (He was shocked, then put his Math } \\
\text { book to his bag. While lowering his } \\
\text { head, he opened his Indonesian } \\
\text { Language book.) }\end{array}$ \\
\hline 4. & $\begin{array}{l}\text { Indonesian language } \\
\text { learning in eighth } \\
\text { grade }\end{array}$ & $\begin{array}{l}\text { The teacher scolded Ubay who } \\
\text { used derogatory words in } \\
\text { calling his friends. The teacher } \\
\text { wished to ask Ubay to call his } \\
\text { friends using a nice term of } \\
\text { address or term of endearment. }\end{array}$ & Teacher: & $\begin{array}{l}\text { Ubay, panggilah temanmu dengan, } \\
\text { panggilan yang disukai!" } \\
{[\text { Me-135/Tl] }} \\
\text { "Ya, Bu." } \\
\text { (Ubay kaget dan tersenyum malu } \\
\text { kemudian dengan lirih menjawab) } \\
\text { "Ubay, call your friend's name using a } \\
\text { nice term of address!" } \\
\text { "Yes, mam." } \\
\text { (Ubay was taken aback and smiled } \\
\text { shyly and answered softly) }\end{array}$ \\
\hline 5. & $\begin{array}{l}\text { Indonesian } \\
\text { language subject } \\
\text { learning in ninth } \\
\text { grade. }\end{array}$ & $\begin{array}{l}\text { The teacher saw a student } \\
\text { named Ade was present after } \\
\text { two weeks absent. With a } \\
\text { declarative structure } \\
\text { (sarcastic tone) the teacher } \\
\text { intended to reprimand and told } \\
\text { him to be diligent in going to } \\
\text { school, not skipping anymore. }\end{array}$ & Teacher: & $\begin{array}{l}\text { "Rupanya hari ini kita dapat murid } \\
\text { baru. Selamat bergabung Ade, Sudah } \\
\text { lama kita tidak bertemu ya. } \\
\text { [Me-155/TTl/Int] } \\
\text { "We got a new student, Welcome Ade, } \\
\text { It's been a long time not meeting you." } \\
\text { Ade bowed while leaning against the } \\
\text { wall, smile cynically and lowered her } \\
\text { head. The other students answered: } \\
\text { "Yes, Mam. It's been two weeks." }\end{array}$ \\
\hline
\end{tabular}

Based on the data analysis towards the six communication functions of teachers' directive speech in learning, the structural characteristics and realization of speech act for each communication function were found as can be seen on the table (3) below. 
TABLE 3

STRUCTURAL MARKERS AND REALIZATION OF COMMUNICATION FUNCTION OF TEACHERS' DIRECTIVE SPEECH

\begin{tabular}{|c|c|c|c|}
\hline No. & Communication function & Speech structure marker & Speech act realization \\
\hline 1. & Ordering & $\begin{array}{l}\text { (a) is started with a verb } \\
\text { (b) uses verbs with prefix di-, per-, } \\
\text { verbs with suffix - kan, } \\
\text { verbs with an article-lah, and verbs with } \\
\text { prefix per- and suffix -kan }\end{array}$ & $\begin{array}{l}\text { (a) direct speech (using imperative } \\
\text { structures, function as ordering) } \\
\text { (b) indirect speech (using declarative } \\
\text { and interrogative structure, } \\
\text { functions as ordering) }\end{array}$ \\
\hline 2. & Requesting & $\begin{array}{l}\text { is started with verbs: coba (try), silakan, or } \\
\text { tolong (please) }\end{array}$ & $\begin{array}{l}\text { (a) direct speech (using imperative } \\
\text { structure, functions as asking) } \\
\text { (b) indirect speech (using declarative } \\
\text { and interrogative structure, } \\
\text { functions as asking) }\end{array}$ \\
\hline 3. & Forbidding & $\begin{array}{l}\text { is started with adverb jangan (don't) and } \\
\text { phrase nggak boleh (should not) }\end{array}$ & $\begin{array}{l}\text { (a) direct speech (using declarative } \\
\text { and interrogative structure, } \\
\text { functions as forbidding) } \\
\text { (b) indirect speech (using declarative } \\
\text { and interrogative structure, } \\
\text { function as forbidding) }\end{array}$ \\
\hline 5. & Asking & $\begin{array}{l}\text { (a) uses questions marks (apa, siapa, berapa, } \\
\text { bagaimana, mengapa, siapa, kapan, dan } \\
\text { di mana) } \\
\text { (b) uses particle }- \text { kah } \\
\text { (c) uses "asking" tone }\end{array}$ & $\begin{array}{l}\text { Direct speech (using interrogative } \\
\text { structure, functions as asking) }\end{array}$ \\
\hline 6. & Inviting & is started with ayo and mari & $\begin{array}{l}\text { Direct speech (using imperative } \\
\text { structure, functions as inviting) }\end{array}$ \\
\hline
\end{tabular}

Furthermore, they were implemented in Indonesian language learning in junior high school by using the synectic model. This model was used because it is oriented towards the students' creativity through teachers' speech based on analogies and metaphors. The results of the study entitled "Indonesian language learning based on teachers' directive speech act strategy and students' positive affective color response with synectic model" are presented based on the objectives of the study as revealed in the introduction as follows.

\section{A. The Purpose of Using Indonesian Language Learning Based on TDSAS-SPACR with the Synectic Model}

The general purpose of using the synectic learning model is the personal development of creativity and creative problem-solving (Weil et al. 1978: 7). Gordon's creative ideas are described in detail by Joyce (2012: 252-253) based on the four views; 1) creativity is important in daily activities. The model is designed to increase the capacity of problem-solving, creative expression, empathy, and insight into social relations. 2) The creative process is not constantly mysterious, everything can be expressed and trained with certain procedures. 3) The creative innovation in all fields - art, science, and engineering - is considered equal and characterized by the same intellectual process. 4) the invention of individual and group creative mindsets is merely the same.

The specific purpose of using TDSAS-SPACR in writing class in Indonesian language subject is the students are able to (1) discover and develop ideas creatively into a creative writing through analogy and metaphor which include these following steps: (a) current situation description, (b) direct analogy, (c) personal analog, (d) solid conflict, (e) direct analogy based on solid conflict, (f) initial tasks rechecking; (2) determine the ideas used as topics in writing through two synectic strategies; creating something new and making something unfamiliar become familiar thing (3) develop ideas into writing through two synectic strategies; creating something new and making something the strange familiar.

By using this synectic model, the students' basic needs fulfillment- love and affection- can emerge their potential and creativity optimally. This is fully described in Sumarti, et al (2018) who confirm the importance of teacher' directive speech strategy in learning.

\section{B. The Design of Indonesian Language Learning Based on TDSAS-SPACR with Synectic Model}

The design of Indonesian language learning based on TDSAS-SPACR- with a synectic model is described as follows: 
TABLE 4

THE DESIGN OF LEARNING BASED ON TDSAS-SPACR WITH SYNECTIC MODEL

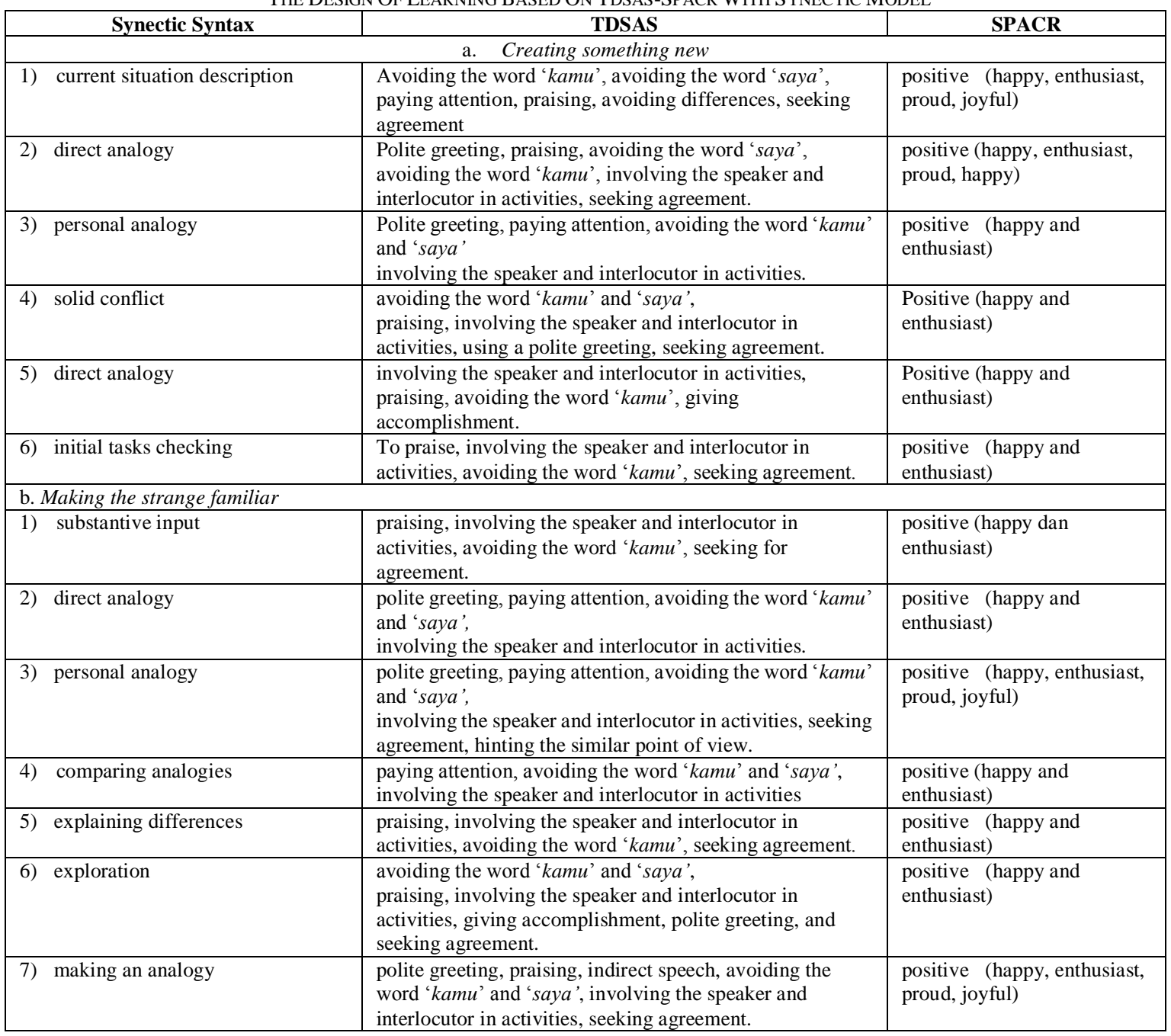

\section{The Effectiveness of the Use of Indonesian Language Learning Based on Teachers' Directive Speech Act Strategy} (TDSAS) and Students' Affective Color Response (SPACR) with Synectics Model

The complete notion of the effectiveness of the use of Indonesian language learning based on TDSAS-SPACR with synectics model is described as follow:

TABLE 5

THE PROCESS OF INDONESIAN LANGUAGE LEARNING BASED ON TDSAS-SPACR WITH A SYNECTIC MODEL IN JUNIOR HIGH SCHOOL

\begin{tabular}{|c|c|c|c|c|}
\hline $\begin{array}{c}\text { The Steps of Synectic } \\
\text { Model }\end{array}$ & Teacher's Activities & Students Activities & TDSAS & SPACR \\
\hline Opening activities & $\begin{array}{l}\text { The teacher conditions the } \\
\text { class by leading the } \\
\text { students to pray, checking } \\
\text { attendance, and doing } \\
\text { apperception }\end{array}$ & $\begin{array}{l}\text { Students pray and listen to } \\
\text { the teacher who staring the } \\
\text { class }\end{array}$ & $\begin{array}{l}\text { a) Direct speech } \\
\text { b) involving } \\
\text { speakers and } \\
\text { interlocutor } \\
\text { c) avoiding } \\
\text { using the words } \\
\text { saya }\end{array}$ & neutral \\
\hline $\begin{array}{l}\text { Core Activities } \\
\text { Step 1: describing current } \\
\text { situation }\end{array}$ & $\begin{array}{l}\text { a) tells an analogy to the } \\
\text { students about their trip to } \\
\text { school. } \\
\text { b) shows a picture of a frog } \\
\text { on slide } \\
\text { c) stimulates the students to } \\
\text { express what can be done } \\
\text { on frogs procedurally }\end{array}$ & $\begin{array}{l}\text { a) listen to the teacher } \\
\text { and ask questions } \\
\text { b) pay attention to a } \\
\text { picture of frog and answer } \\
\text { the teacher's question. } \\
\text { c) mention some ways } \\
\text { that can be done to the frog } \\
\text { procedurally }\end{array}$ & $\begin{array}{l}\text { a) increase } \\
\text { attention } \\
\text { b) seeking for } \\
\text { agreement } \\
\text { d) direct } \\
\text { speech } \\
\text { e) praising } \\
\text { f) indirect } \\
\text { speech }\end{array}$ & $\begin{array}{l}\text { neutral } \\
\text { happy }\end{array}$ \\
\hline $\begin{array}{l}\text { Step 2: } \\
\text { Direct Analogy }\end{array}$ & $\begin{array}{l}\text { a) The teacher asks students } \\
\text { to choose one of the }\end{array}$ & $\begin{array}{l}\text { Students propose direct } \\
\text { analogies, choose and }\end{array}$ & $\begin{array}{l}\text { a) direct speech } \\
\text { b) involving }\end{array}$ & $\begin{array}{l}\text { neutral } \\
\text { happy }\end{array}$ \\
\hline
\end{tabular}




\begin{tabular}{|c|c|c|c|c|}
\hline & $\begin{array}{l}\text { procedures performed on } \\
\text { the frog } \\
\text { b) the teacher invites } \\
\text { students to write down the } \\
\text { steps to dissect frogs as } \\
\text { they have done in the } \\
\text { laboratory. }\end{array}$ & explore them further. & $\begin{array}{l}\text { speaker and } \\
\text { interlocuter } \\
\text { c) avoiding } \\
\text { using the words } \\
\text { saya and kamu } \\
\text { d) increase } \\
\text { attention } \\
\text { e) praising } \\
\text { f) using jokes }\end{array}$ & proud \\
\hline $\begin{array}{l}\text { Step 3: } \\
\text { Personal Analogy }\end{array}$ & $\begin{array}{l}\text { The teacher invites students } \\
\text { to develop procedures to } \\
\text { dissect frogs in sequential } \\
\text { and logical steps. }\end{array}$ & $\begin{array}{l}\text { Students act as the analogy } \\
\text { they have chosen in the } \\
\text { second step. }\end{array}$ & $\begin{array}{l}\text { a) praising } \\
\text { b) involving } \\
\text { speakers and } \\
\text { interlocutor } \\
\text { c) paying } \\
\text { attention to } \\
\text { interlocutor's } \\
\text { needs } \\
\text { d) direct speech } \\
\text { e) greeting by } \\
\text { using the term of } \\
\text { endearment }\end{array}$ & \\
\hline $\begin{array}{l}\text { Step 4: } \\
\text { solid conflict }\end{array}$ & $\begin{array}{l}\text { The teacher tells the } \\
\text { students to develop each } \\
\text { step in the procedure to } \\
\text { dissect frogs into complete, } \\
\text { cohesive and coherent } \\
\text { sentences. }\end{array}$ & $\begin{array}{l}\text { Students take the } \\
\text { descriptions from the } \\
\text { second and third steps, } \\
\text { proposing some analogies of } \\
\text { solid conflict and choosing } \\
\text { one of them. }\end{array}$ & $\begin{array}{l}\text { a) directive } \\
\text { speech } \\
\text { b) involving } \\
\text { speaker and } \\
\text { interlocutor } \\
\text { c) avoid using } \\
\text { the words saya } \\
\text { and kamu } \\
\text { d) increase } \\
\text { attention } \\
\text { e) praising } \\
\text { f) using jokes } \\
\end{array}$ & $\begin{array}{l}\text { neutral } \\
\text { happy } \\
\text { proud }\end{array}$ \\
\hline $\begin{array}{l}\text { Step 5: } \\
\text { direct analogy }\end{array}$ & $\begin{array}{l}\text { The teacher asks students to } \\
\text { make an analogy of } \\
\text { dissecting frogs with other } \\
\text { ideas, such as building a } \\
\text { house or } \\
\text { disassembling/fixing a } \\
\text { bicycle }\end{array}$ & $\begin{array}{l}\text { Students create and choose } \\
\text { other direct analogies based } \\
\text { on solid conflict }\end{array}$ & $\begin{array}{l}\text { a) indirect } \\
\text { speech } \\
\text { b) praising } \\
\text { c) direct speech } \\
\text { d) greeting by } \\
\text { using term of } \\
\text { endearment } \\
\text { e) seeking for } \\
\text { agreement }\end{array}$ & $\begin{array}{l}\text { neutral } \\
\text { happy } \\
\text { joyful } \\
\text { proud }\end{array}$ \\
\hline $\begin{array}{l}\text { Step 6: rechecking initial } \\
\text { tasks }\end{array}$ & $\begin{array}{l}\text { The teacher asks students to } \\
\text { return to the initial } \\
\text { assignment or problem and } \\
\text { use the final analogy and / } \\
\text { or the whole synectic } \\
\text { experience }\end{array}$ & $\begin{array}{l}\text { a) students arrange the steps } \\
\text { of the chosen ideas } \\
\text { procedurally. } \\
\text { b) students develop the steps } \\
\text { into a complete essay }\end{array}$ & $\begin{array}{l}\text { a) direct speech } \\
\text { b) involving } \\
\text { speaker and } \\
\text { interlocutor } \\
\text { c) avoid using } \\
\text { the words saya } \\
\text { and kamu } \\
\text { d) increasing } \\
\text { attention } \\
\text { e) praising } \\
\text { f) seeking for } \\
\text { agreement }\end{array}$ & $\begin{array}{l}\text { neutral } \\
\text { happy } \\
\text { proud }\end{array}$ \\
\hline Closing Activities & $\begin{array}{l}\text { a) the teacher evaluates by } \\
\text { inviting students to read the } \\
\text { results of their writing in } \\
\text { front of the class which } \\
\text { then are responded by all } \\
\text { students } \\
\text { b) The teacher and students } \\
\text { summarize and reflect the } \\
\text { learning of that day. }\end{array}$ & $\begin{array}{l}\text { a) reading the results of the } \\
\text { writing then responded by } \\
\text { all friends } \\
\text { b) summarize and reflect the } \\
\text { learning (together with the } \\
\text { teacher). }\end{array}$ & $\begin{array}{l}\text { a) indirect } \\
\text { speech } \\
\text { b) praising } \\
\text { c) direct speech } \\
\text { d) greet with a } \\
\text { term of } \\
\text { endearment } \\
\text { d) avoiding } \\
\text { using the words } \\
\text { saya } \\
\text { and kamu } \\
\text { e) paying } \\
\text { attention } \\
\text { f) seeking } \\
\text { agreement } \\
\text { g) involving } \\
\text { speaker and } \\
\text { interlocutor }\end{array}$ & $\begin{array}{l}\text { neutral } \\
\text { happy }\end{array}$ \\
\hline
\end{tabular}

In addition to the results of observations on Indonesian language learning based on teachers' directive speech act strategy (TDSAS) and students' positive affective color response (SPACR) with synectics model, the results of students' 
answers to the open questionnaire techniques about their reflection on the learning conducted were also obtained. Based on the qualitative data analysis, the students' answers to the open questionnaire revealed that all the students (100\%) were happy to take part in the learning and the language used by the teacher was easily understood. It increased the students' motivation and enthusiasm for learning, and they were not tense nor bored.

The learning outcomes of writing skills have significantly increased after using TDSAS-SPACR- based learning model. Before using the model, the mean score of students' writing skills was 67 and after using the model, the mean score increased to 81 . Therefore, the empirical validity of TDSAS-SPACR-based learning with a synectic model was effective. The effectiveness of learning can be seen from the success of the learning process and result. Therefore, further research on TDSAS-SPACR-based learning with a synectic model in a broader scale experimental study should be done.

\section{CONCLUSION AND SUGGESTION}

Love and self-esteem as the students' basic needs can be accommodated by teachers' directive speech act strategy (TDSAS). TDSAS which emerges the students' positive affective color response (SPACR) to create an effective, fun and conducive to learning and also improve students' confidence can be applied to preserve the students' feeling, to feel loved and appreciated.

Based on the empirical validity test, Indonesian language learning based on teachers' directive speech act strategy in junior high school and students' positive affective color response with a synectic model can increase the quality and learning outcomes. By using that model, Indonesian language learning in junior high school is fun and effective.

\section{REFERENCES}

[1] Alwasilah, C. (2002). Pokoknya kualitatif (It has to be qualitative). Jakarta: Dunia Pustaka Jaya.

[2] Brown, P. dan Levinson, S.C. (1987). Universal in language use: Politeness phenomena. In Esther N. Goody (editor) Question and politeness. Cambridge: Cambridge University Press.

[3] Dascal, M. (1983). Pragmatics and the philosophy of mind. Amsterdam: John Benjamins.

[4] Davidson, R.J. (2009). List of emotions - human emotion chart. Retrieved from http: http://www.findingauthentichappiness.com/list-of-motions.html.

[5] Diener, E., Smith H., dan Fujita F. (1995). The personality structure of affect. Journal of Personality and Social Psychology. 50: $130-140$

[6] Fried, L.J. (2011). Emotion and motivation regulation strategy use in the middle school classroom. Australian Journal of Teacher Education. Volume 36. Retrieved from http//www.ecu.edu.au/egi/viewcontent.egi/article=1543\&context=ajte.

[7] Joyce, B. Marsha, W. and Emily. C. (2011). Models of teaching. Eighth Edition. USA Pearson Education, Inc.

[8] Maslow, A.H. (1954). Motivation and personality. New York: Harper\&Row.

[9] McDonald, Emma S. and Dyan M. Hershman. (2011). Guru dan kelas Cemerlang [Teacher and brilliant class]. Jakarta: PT Indeks,

[10] Ormrod, J.E. (2009). Educational psychology developing learners, Sixth Edition. Prentice Hall: Pearson Education

[11] Pekrun, Reinhard, et al. (2011). Measuring emotions in students' learning and performance: The Achievement Emotions Questionnaire (AEQ). Contemporary Educational Psychology. Volume 36, hlm.36-48

[12] Yule. G. (1996). Pragmatics. New York: Oxford University Press.

[13] Yusuf, L.N.S. (2005). Psikologi perkembangan anak dan remaja [Psychology of children and adolescents' development]. Bandung: PT Remaja Rosdakarya.

[14] Sumarti. (2015). Strategi tindak tutur direktif guru dan respons warna afektif siswa [Teacher's directive speech act strategy and students' affective color response]. Proceeding of conference ADOBSI. Surakarta: FKIP UNS.

[15] Sumarti, ling Sunarti, Mulyanto Widodo. (2018). The Fulfilment of student's deficiency need by teacher's directive speech act strategy. Proceedings of the fourth Prasasti international seminar on linguistics. Atlantis Press. Doi: https://dot.org/10.2991/prasasti-18.2018.80.

[16] Zhang, Q. (2011). Teacher request politeness: effects on student positive emotions and compliance intention. Journal of Human Communication. A Publication of the Pacific and Asian Communication Association. Vol. 14, No 4, hlm. 347-356.

Sumarti, M. Hum. was born in Cirebon. West Java, Indonesia, on March 18th, 1970. She completed her undergraduate degree at the Indonesian Language and Literature Study Program IKIP Bandung in 1992. In 1998, she earned her master's degree in the Literature Study Program with Linguistics concentration in Padjadjaran University Bandung. She merited her doctoral degree in Indonesian Language Education at Indonesia University of Education (UPI) Bandung. Her field of specialization is Indonesian Language Education.

Since 1994, Sumarti has become a lecturer in Indonesian language and literature education, Faculty of Education and Teacher Training, the University of Lampung for undergraduate students. In 2015, she started teaching in a master's program in the Indonesian language and literature education and master program in Lampungese Language and Literature Education. She teaches linguistics, phonology, syntax, Indonesian structure, semantics, journal review, problematic learning of Indonesian Language and Literature and Learning Indonesian Speaking Skills for speakers from other languages. Her focus and interest of research are linguistics and its application in Indonesian language learning

She joins Indonesian Language and Literature Lecturer Association (Asosiasi Dosen Bahasa dan Sastra Indonesia/ADOBSI), Indonesian Linguistics Society (Masyarakat Linguistik Indonesia/MLI), Indonesian Regional Culture Lecturer Association (Ikatan 
Dosen Budaya Daerah Indonesia/ IKADBUDI), and Association of Indonesian Cultural Scholars (Himpunan Sarjana Kebudayaan Indonesia/ HISKI). She has published several publications; (1) Strategi Tindak Tutur Direktif Guru dan Respons Warna Afektif Siswa (UPI Educational Research Journal, 2015), (2) Prinsip Tenggang Rasa Masyarakat Etnis Cirebon di Pulau Pasaran Bandar Lampung (IKADBUDI International Conference Proceeding, 2016), (3) Pembelajaran Berbicara Berbasis Tipologi Bahasa dan Kearifan Lokas bagi Penutur Asing di Universitas Lampung (International Conference Proceeding of Teaching Indonesian to speakers of other languages KIPBIPA X, 2017), (4) Bahasa Cirebon di Pulau Pasaran Bandar Lampung (International Conference Proceeding, 2017), (5) Faktor-Faktor yang Menentukan Pemilihan Bentuk Sapaan Bahasa Lampung Pubian (International Conference Proceeding, 2018), dan (6) The Fulfilment Of Student's Deficiency Need By Teacher' S Directive Speech Act Strategy Which Get Positive Affective Color Response (Thomson Reuters, 2018).

Iing Sunarti, M.Pd. was born in Sukabumi, West Java, Indonesia, on November 16th, 1958. She earned her undergraduate degree in Indonesian language and literature education of faculty of teacher training and education, University of Lampung. She then continued her master in the same program in Indonesia University of Education and earned her doctoral degree at Gajah Mada University in 2016

ling has become a lecturer in Indonesian language and literature education, Faculty of Education and Teacher Training, the University of Lampung for undergraduate students since 1987. She is now also teaching a master's program in the Indonesian language and literature education and master program in Lampungese Language and Literature Education. She teaches linguistics, sociolinguistics, psycholinguistics, semantics, language research methods, and speaking class. She interested in Indonesian language and literature education.

Iing Sunarti joins the Indonesian Linguistics Society (Masyarakat Linguistik Indonesia/MLI), Indonesian Regional Culture Lecturer Association (Ikatan Dosen Budaya Daerah Indonesia/ IKADBUDI), and Association of Indonesian Cultural Scholars (Himpunan Sarjana Kebudayaan Indonesia/ HISKI). She has published some articles such as (1) Tutur/Tutor Bahasa Lampung (International Conference Proceeding IKADBUDI, 2016), (2) Etika Budaya Bertutur Sapa Masyarakat Etnis Lampung (National Seminar Proceeding, 2017), (3) Faktor-Faktor yang Menentukan Pemilihan Bentuk Sapaan Bahasa Lampung Pubian (International Seminar Proceeding, 2018), (4) Bahasa Cirebon di Pulau Pasaran Bandar Lampung (International Seminar, 2018), and (5) (6) The Fulfilment Of Student's Deficiency Need By Teacher' S Directive Speech Act Strategy Which Get Positive Affective Color Response (Thomson Reuters, 2018).

Mulyanto Widodo, M.Pd. was born in Purbolinggo on February 3rd, 1962. He earned his undergraduate degree at the Indonesian Language and Literature Study Program, Faculty of Teacher Training and Education, the University of Lampung in 1986. He completed his master's degree in the Indonesian Language and Literature Study Program at Indonesia University of Education and inn 2009, he got his doctoral degree in the same program and the same university.

Since 1988, Mulyanto has become a lecturer in Indonesian language and literature education, Faculty of Education and Teacher Training, the University of Lampung for undergraduate students. He teaches the theory of language learning, research on language, morphology, and language learning design. He is now also teaching a master's program in the Indonesian language and literature education and master program in Lampungese Language and Literature Education. His focus and interest in research are Indonesian Language Education.

He joins Indonesian Linguistics Society (Masyarakat Linguistik Indonesia/MLI), Indonesian Regional Culture Lecturer Association (Ikatan Dosen Budaya Daerah Indonesia/ IKADBUDI), and Association of Indonesian Cultural Scholars (Himpunan Sarjana Kebudayaan Indonesia/ HISKI). He has published several publications; (1) Mari Mendudukkan Fungsi Bahasa Indonesia Sesuai dengan Kedudukannya (Kelasa, 2010) (2) Kemampuan Menyusun Laporan Kelompok Berdasarkan Penilaian Bersama Mahasiswa FKIP Unila (Aksara Journal, 2010), dan (3) Eksistensi Tiga Tokoh "SAMPAR" dalam menghadapi Absurditas (Aksara Journal, 2010). 